This article was downloaded by: [The University of Manchester Library]

On: 03 April 2013, At: 09: 10

Publisher: Routledge

Informa Ltd Registered in England and Wales Registered Number: 1072954 Registered

office: Mortimer House, 37-41 Mortimer Street, London W1T 3J H, UK

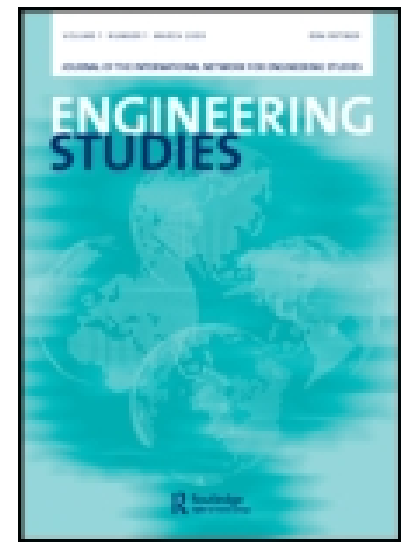

\title{
Engineering Studies
}

Publication details, including instructions for authors and subscription information:

http:// www. tandfonline.com/loi/ test20

\section{Bacterial cultures: ontologies of bacteria and engineering expertise at the nexus of synthetic biology and water services}

\author{
Andrew S. Balmer ${ }^{a} \&$ Susan Molyneux-Hodgson ${ }^{b}$ \\ a Sociology, University of Manchester, Arthur Lewis Building, \\ Oxford Road, Manchester, M139PL, UK \\ ${ }^{b}$ Sociology, University of Sheffield, Sheffield, South Yorkshire, UK \\ Version of record first published: 05 Feb 2013.
}

To cite this article: Andrew S. Balmer \& Susan Molyneux-Hodgson (2013): Bacterial cultures: ontologies of bacteria and engineering expertise at the nexus of synthetic biology and water services, Engineering Studies, 5:1, 59-73

To link to this article: http:// dx. doi.org/ 10.1080/ 19378629.2013.766198

\section{PLEASE SCROLL DOWN FOR ARTICLE}

Full terms and conditions of use: http://www.tandfonline.com/page/terms-and-conditions

This article may be used for research, teaching, and private study purposes. Any substantial or systematic reproduction, redistribution, reselling, loan, sub-licensing, systematic supply, or distribution in any form to anyone is expressly forbidden.

The publisher does not give any warranty express or implied or make any representation that the contents will be complete or accurate or up to date. The accuracy of any instructions, formulae, and drug doses should be independently verified with primary sources. The publisher shall not be liable for any loss, actions, claims, proceedings, demand, or costs or damages whatsoever or howsoever caused arising directly or indirectly in connection with or arising out of the use of this material. 


\title{
Bacterial cultures: ontologies of bacteria and engineering expertise at the nexus of synthetic biology and water services
}

\author{
Andrew S. Balmer ${ }^{\mathrm{a} *}$ and Susan Molyneux-Hodgson ${ }^{\mathrm{b}}$ \\ ${ }^{a}$ Sociology, University of Manchester, Arthur Lewis Building, Oxford Road, Manchester

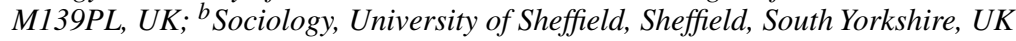

(Received 10 May 2012; final version received 6 December 2012)

\begin{abstract}
In this paper we report on ethnographic work developed over two years, working as social scientists within a project on synthetic biology (SB), which aimed to use engineered bacteria as solutions to water industry problems. We were asked to help solve the 'barrier to innovation' by our engineering colleagues who believed that industrial and public ignorance would block their innovations. Instead of orienting around 'ignorance' we chose to explore the different ontologies of bacteria that were adopted in the various practices of the many sites involved in the project. We describe our observations in microbiological laboratories and compare them to a waste water treatment facility. Engineers in the lab understand bacteria as controllable but also vulnerable, thus their ability to manipulate and protect bacteria becomes important in their claims to expertise. In contrast, engineers in the water facility understand bacteria as dangerous, but they become skilled in protecting their bodies, make sense of their relation to bacteria through immunological narratives and claim expertise through an olfactory epistemology. Overall, we conclude that the ontologies of 'engineer' and 'bacteria' are interrelated through context-specific practices. Finally, we argue that this account is instructive for current policy and engagement discussions around SB.
\end{abstract}

Keywords: meanings of bacteria; ontologies; synthetic biology; water industry; engineering identity

\section{Introduction}

This paper reports on our ethnographic work, as two sociologists of science, in the midst of a synthetic biology (SB) project that sought to make bacteria useful to the water industry. As part of this work we followed the meanings that were produced in relation to bacteria, and here we report on two settings in which the meanings of bacteria contrasted. First, we relate meanings made by self-defined academic synthetic biologists in relation to bacteria in the microbiology laboratory; and second, by industrial process engineers ${ }^{1}$ in relation to bacteria in the water treatment facility.

What constitutes a 'synthetic biologist' or 'SB' is a rather murky business at the moment. Nonetheless, we might venture that the guiding principle in the formation of the heterogeneous assemblage increasingly consolidated as SB is the bringing together of biological material and engineering logos. ${ }^{2}$ Certainly, a defining feature of this emerging

\footnotetext{
*Corresponding author. Email: andrew.balmer@manchester.ac.uk

${ }^{1}$ The term used by the respondents themselves to describe their work of operating and maintaining the water treatment facility.

${ }^{2}$ O’Malley et al., "Knowledge Making Distinctions."
} 
techno-science is the manipulation of the bacterial world by engineers of one sort or another, and thus also a desire to control the supposedly unruly life of microbes in a more industrially advantageous manner.

Against this background, one small research project in the UK conceived of itself as having the characteristics of the SB genus and sought to provide access to the biological realm for engineers in water services. The (partial) adoption of the SB epistemology, rhetoric and ethos became instrumental in articulating a vision of a water infrastructure that could finally take control of the microorganisms that are ubiquitous in the water system. In pursuit of that goal the scientific research team chose two case studies to investigate: (1) to develop a novel pathogen detection system using bacteria; and (2) to investigate the potential of bacteria to reduce friction in sewerage pipes. A third case study in the project was to explore the sociological aspects of the two technical cases, including any so-called 'barriers to innovation' that might obstruct the engineer's aspirations.

One feature of the ready-formatted construction of a barrier to innovation, evident from the outset of the project, was the expectation of academic engineers (water engineers, chemical engineers and biological engineers alike) of resistance from water companies, regulators, industrial engineers and 'the public' to the use and release of genetically engineered bacteria in water infrastructure. The academics' fear that the science would be rejected by an ignorant public or pandering industry neatly fit the model of the now classic 'GMO/public ignorance' rhetoric that remains well-entrenched in the discourse of genetic engineering and is now thoroughly enmeshed with $\mathrm{SB} .{ }^{3}$ In response to our academic colleagues' (often implicit) use of this account, our aim in this third package of research thus became to find a way to challenge the notion that the public and the water service employees were simply ignorant of bacteria and their synthetic promise. Instead of assuming ignorance, we took the meanings of bacteria as a point of departure, endeavouring to describe how bacteria became sensible in the local cultures of the laboratory and the waste water treatment facility. In doing so, we began to articulate an alternative account of these 'barriers' and though we began with the same premise as our engineering colleagues, that there might be so-called 'barriers to innovation', we proceeded along a different pathway to reach a different description of the problem. We argue that such work is not only sociologically interesting but has real implications for how we think about and respond to 'barriers', regulation and public engagement in the context of a socio-technical innovation system such as SB.

The paper draws on an evidence base of ethnographic work (primarily observational but also involving formal interviews with colleagues at the beginning, in the middle and at the end of the project), coupled with analysis of governmental and industrial documents and participation in 'industry days' where academics, industry representatives and regulators met. Data was collected over the duration of the research project, namely January 2010 April 2011 (and more informally for a period afterwards) and was gathered over multiple research sites including university laboratories, offices, meeting rooms, sewage works and on the streets. ${ }^{4}$ We both collected ethnographic notes in these many and varied locations and regularly met to discuss our work. We also regularly discussed findings with other colleagues as part of an ESRC seminar series on SB. In this paper we focus on two types of location: laboratories and sewage treatment facilities.

\footnotetext{
${ }^{3}$ Marris, "Elephant in the Room."

${ }^{4}$ Marcus, "Ethnography in/of the World System."
} 


\section{Barriers to innovation and public perception}

There were two principle rationales at work in academic understandings of the 'barrier to innovation', the first having to do with industrial conservatism and the second having to do with industrial and public ignorance. Several of the engineers in the academic team had many years of experience of working with water service companies and had come to hold the rather obstinate opinion that industrial actors and companies as a whole are conservative when it comes to technological innovation. The reasons for this were varied but often rested on a critique of governance and regulation of the industry. Engineers saw regulation as being too heavy-handed because of the public health concerns around water provision and thus as stifling innovation that might otherwise improve water quality, service, costs, etc. Comparisons were often made to the pharmaceutical industry, championed as an innovative, pioneering, future-oriented business as compared to the staid, Victorian, short-termism of the water industry. One water engineer described it thus:

[following mention of barriers by the engineer]

$\mathrm{AB}$ : What are the barriers then? Why is that, why is it a problem you foresee?

Water engineer \#2: You only have to look at the problems and challenges they've got, the industry has, the critiques the water industry has of taking on new technologies, of relatively incremental nature, so like a new way of detecting leakage with noise, takes ten years to get to industry. ... [with Synthetic Biology] we're talking about a total re-think, re-change of what they're going to do! There's a huge barrier there, from everything, from the kind of the pure company perspective, what's the cost-benefit? What's the confidence of it? Through to the DWI, to the high-level of policy, of DEFRA, government saying it's okay. Also the public perception of accepting what we're trying to do.

Here our engineering colleague describes the various considerations (principally financial and regulatory) that would be potential barriers to the uptake of their SB solutions. In one meeting, a member of the project who had worked with the water industry for many years bemoaned the ignorance of the industrial employees, complaining of their lack of understanding of biology and their kowtowing to public perceptions.

Other academics on the project articulated the anticipated resistance of the industry in similar terms and linked it to the public's negative perception of SB as uncontrolled and uncontrollable. For example, by enrolling the then recently published BBSRC Public Dialogue Report on SB, ${ }^{5}$ one researcher connected public concerns up to the fear of uncontrolled release:

Chemical/Environmental engineer \#1: And I think there was a study done, that Royal Society study, where they had the groups together to look at the social implications and everyone was fine with synthetic biology until you started talking about it in the environment, and that's a huge problem with this.

AB: Why do you think that is?

Chemical/Environmental engineer \#1: I think 'cause everyone views it's uncontrolled, it's uncontained, and clean drinking water is my right, which I don't necessarily agree with, and if you put something in it to, in an uncontrolled, uncontained way, then it's going to turn into the big monster, I think that's part of the problem.

In such a narrative the industry and public understanding of SB, or of genetically engineered microorganisms more generally, is often caricatured using the child-like language of 'monsters' and fears. The focus is often on how public actors do not understand how controlled and contained the bacteria are. In our ethnographic work more nationally, attending

\footnotetext{
${ }^{5}$ Bhattachary et al., "Synthetic Body Dialogue."
} 
the events organised by government, research groups and funders, in meeting after meeting, conference after conference, the same assumptions about public ignorance of SB were re-hashed.

Indeed, this is an exceptionally obstinate position, in which non-scientist actors are positioned as simply adopting opinions on science that are spoon-fed by pressure groups or lazy journalists. The understanding of our synthetic biologist colleagues thus seems to be that there is simply one correct account of bacteria in SB, the scientific/engineering one, and that others represent distortions and misunderstandings. In addressing the 'barrier to innovation' that the project posed to us, we took a different position, developed through existing literature in science and technology studies (STS) and engineering studies, in order to open a different account of understandings of bacteria.

\section{Ontologies of bacteria and engineers}

STS has a longstanding interest in epistemology, which, coupled to its more recent 'ontological turn', has produced a picture of scientific objects that are decidedly situated, not only within spatial contexts (both local and global) ${ }^{6}$ but also within practices. Our work continues in this tradition, taking note of some of the empirically developed theoretical lessons that it offers, in order to examine the ways in which bacteria and disciplined individuals are interrelated in specific contexts.

The tradition of laboratory studies has instructively documented the socio-technical work that goes into constituting objects of knowledge. For example, Knorr-Cetina uses her notion of 'epistemic cultures' to argue that sociological analyses can not only help us understand the "construction of knowledge but [also] the construction of the machineries of knowledge construction'.7 A critical step in such an orientation is to take interest not simply in the objects of knowledge but in the practices in which they are constituted. The attention to practices helps shift our sociological gaze away from too rigid a focus on human interests and intentions and reorients them instead to the 'dynamics of the chains of action of collective life' ${ }^{8}$ Whilst the insistence on cultures in such STS work reminds us to attend to the symbolic meanings of these practices, it also emphasises how non-human objects are important actors in these chains of action. This has been cogently argued in the context of 'actor network theory', ${ }^{9}$ which is resolute in its rejection of a given distinction between human and nonhuman, social and natural. Instead, such work attends to the ways in which these distinctions are themselves a product of interactions within heterogeneous networks. In this respect, the notion of 'objects' as somehow determined by their own qualities or as simply given meaning by human actors is defunct and instead objects (and categories) both human and non-human have to be understood by virtue of their contextual relations with each other.

This marks an important ontological disposition. For example, Mol argues 'that ontology is not given in the order of things, but that, instead, ontologies are brought into being, sustained, or allowed to wither away in common, day-to-day, sociomaterial practices' ${ }^{10}$ In this regard, our tracing of chains of engineering action from laboratory practices, into

\footnotetext{
${ }^{6}$ Law and Mol, "Situating Technoscience."

${ }^{7}$ Knorr-Cetina, Epistemic Cultures, 3.

${ }^{8}$ Ibid., 10.

${ }^{9}$ For example, see Latour, Reassembling the Social.

${ }^{10} \mathrm{Mol}$, Body Multiple, 6.
} 
offices, streets and water treatment facilities has also been a tracing of the ontologies of 'bacteria' and 'engineer' that are sustained or challenged through the contextual relations of human and non-human actors.

Engineering studies has followed some similar lines of argument, borrowed from STS, but has also extended its findings and objects of interest. For example, paralleling early laboratory ethnographies, studies of engineering and design also showed how social processes were at work in creating technical objects and order. ${ }^{11}$ This helped demonstrate how socially constructed design practices embedded various norms and values.

One major concern in the field has been with the ontological status of engineers, or - in the more commonly used phraseology from this scholarship - with 'engineering identities'. Vinck and colleagues ${ }^{12}$ have argued that engineering objects and identities are importantly tied to local practices. This ethnographic work with engineers and designers has shown, for instance, that a number of contextually implicit rules and procedures are at work in engineering and design. Ravaille and Vinck ${ }^{13}$ argue that different contexts thus constitute different 'design cultures'. Bovy and Vinck ${ }^{14}$ show how material objects are significant actors in the development of engineering solutions and argue that an engineer's identity is changed by the process of such work. Paretti and McNair show how engineering identities are discursively claimed and contested in local contexts. ${ }^{15}$ Articulating how engineers 'respond' to 'codes of meaning' in different national contexts, Downey and Lucena point out that, 'The identity politics of engineers is always ontological work, positioning engineers as material entities in the world amidst other entities'. ${ }^{16}$

In this paper we show how the work on engineering identities, coupled to the emerging work on epistemologies of engineering, can benefit from recent work in STS regarding ontologies and practices. Most significantly, work on engineering identities can be developed by more attention to how these identities are negotiated in relation to the objects with which individuals work. Brought into dialogue, these intertwining trajectories thus pose interesting ontological questions regarding the ways in which engineering identities, such as those of synthetic biologists, are contextually coproduced with epistemic machinery and with the material objects of knowledge. In the context of our work we thus ask, How are the ontologies of 'synthetic biologist'/'process engineer', 'bacteria' and the processes through which such engineers make knowledge about bacteria mutually constituted?

In what follows we explore this question and thus contribute to work in both STS and Engineering Studies. Our substantive contribution lies in the value of the ethnographic work conducted in this emerging field and in the novelty of paying attention to the embodied nature of the relationship between engineer, practices and bacteria. We take interest in how these mutually articulated ontologies have important implications for thinking about engineering expertise and for the current discussions regarding regulation of SB. In the discussion we use these ethnographic descriptions to reflect on the assumption of a 'barrier to innovation' in SB and challenge the continued insistence on ignorance as the central component of problematisation in this context.

\footnotetext{
${ }^{11}$ See, for example, Bucciarelli, "Ethnographic Perspective."

${ }^{12}$ Vinck, Everyday Engineering.

${ }^{13}$ Vinck and Ravaille, "Contrasting Design Cultures."

${ }^{14}$ Bovy and Vinck, "Social Complexity."

${ }^{15}$ Paretti and McNair, "Analyzing the Intersections."

${ }^{16}$ Downey and Lucena, "Knowledge and Professional Identity," 400.
} 


\section{Laboratory cultures: managing bacteria at risk}

Under the name of 'SB', the adoption of engineering epistemology in the work of genetic modification has emphasised traditional engineering principles, including abstraction, standardisation, control and prediction. In this respect, engineering 'culture' is now being applied to manipulation of 'natural' biological objects ${ }^{17}$ so that the natural world comes to mirror the social. As Calvert concludes, "we are seeing a reconstruction of nature that is utilizable and instrumentalizable, and is a product of epistemic ideals and design choices' ${ }^{18}$ Such epistemic machinery understandably constitutes its objects of interest as controlled and predictable.

However, it is not only the logic and rhetoric of SB that imparts this understanding of bacteria. In addition, the practices through which bacteria are manipulated, the spaces in which these practices are enacted, and the sign systems that regulate the safety of these practices are also instrumental in constituting bacteria as controllable. However, as much as the bacteria appear to be under control they simultaneously appear as vulnerable and as at risk. Following Mol's account of ontologies, ${ }^{19}$ we now describe how this ontological position in regards to bacteria emerges through contextually specific practices.

To begin with, when the project was just getting off the ground, we met our SB colleagues in meeting rooms. Grey furniture, projector screens and stain-resistant carpets. The rooms were new and smelled like plastic. In these rooms one struggled to get a sense of the life of the practical work in which the engineers were engaged. Talk was managerial: staff appointments, finances, sequencing the work, working out the parts to be used, trying to make sense of the project and, later, the findings. In fact, the whole building was new: this was a place where science was going to meet industry, and our engineers were very much interested in getting microbes into the water industry. These managerial situations point towards a meaning for bacteria that is primarily instrumental and concurrently devoid of 'life'. It was in the laboratories where the meanings of bacteria - as living entities - became more visibly significant.

In the lab, everything is suddenly white. White walls, white stools, white counters, white powders, white liquids, white equipment. We find ourselves wearing white lab coats. White gloves at the entrance, white gloves on the counter, white gloves stacked onto shelves 3 deep and 10 across. We get used to the feeling of nitrile gloves. The lab is a place where things have to be clean, so there's also a noxious smelling alcohol routinely spritzed and wiped across the counters. Though these features are quite common, microbiology laboratories do differ from group-to-group, floor-to-floor. One group working a lot with yeast, for example, have become quite accustomed to the smell and now only seem to notice it when a newcomer turns-up their nose. Everyone else seems more comfortable with the reassuring smell of $E$. coli. 'You'll get used to it', they say. And you do. After a few weeks the smell seems to disappear. But it is you that has changed, not the smell.

Some of the labs are temperature controlled, whereas others are fine at room temperature. Some have distinctive whirring, clicking or screeching noises created by the specialist equipment. But although they differ in important ways, they nonetheless share a significant common feature: they are all organised in order to safely manipulate the microbiological realm. This organisation, however, is ultimately determined not by the deterrence of release of these unique organisms, but by prevention of infiltration of more common species that might contaminate the lab apparatuses and thus ruin experiments.

\footnotetext{
${ }^{17}$ Calvert, "Synthetic Biology."

${ }^{18}$ Ibid., 109.

${ }^{19} \mathrm{Mol}$, Body Multiple.
} 
Furthermore, aside from the smells, sights and sounds, an important commonality in the experience of working with bacteria, no matter which group we were with, was the embodied, tacit knowledge that all the academic researchers must acquire in order to effectively manipulate the bacterial world in this precarious, white space.

Whatever our colleagues' backgrounds, they all had to face the challenges inherent to working at the level of the microscopic. First, bacteria are invisible to the naked eye and thus a wide range of equipment is necessary to interact with them, so all of the experience of bacteria in the laboratory is mediated by technosemiotic assemblages. The body has to be routinised, as one respondent said, 'You have to acquire "green fingers", meaning you have to become skilled with the everyday equipment in the lab before you can get anywhere with your work.

One also has to learn to see the bacteria in a variety of states as they are transformed by the equipment and procedures into docile objects of analytic knowledge. One has to learn to interact with them as clear liquids when they are being heat-shocked and transformed, as creamy-white colonies on agar, as broth-like fluids in falcon tubes and as glowing green beacons of successful transformation under fluorescent microscopes. There are even more ways in which one learns to understand and experience bacteria that are shaped by the processes of DNA manipulation during $\mathrm{PCR}^{20}$ or gel electrophoresis, ${ }^{21}$ during mini-preps ${ }^{22}$ and the preparation of antibiotics. ${ }^{23}$ These procedures that surround the bacteria and their genetic material all contribute to one potent understanding of the organisms, that of being to see them as manipulable.

Perhaps the most significant experience regarding the management of bacteria in the laboratory, however, has to do with the care and skilful practice that goes into nurturing them to healthy quantities and protecting them from the 'natural' environment. If one follows a bacterial sample through the various spaces in which it is changed, from the freezer where they are kept and into the fire where they are destroyed, from the plates into pipettes, one sees how much of the work of bacterial transformation is shaped by a need to keep these few bacterial specimens safe, to protect them from the dangerous world of the everyday chemicals, enzymes and other organisms that threaten their growth. Thus, a significant amount of work goes into training one's body to be an effective user of laboratory equipment, in order to protect the bacteria from outside forces and from the body itself. This training is a form of what Knorr-Cetina calls 'care-taking' in the laboratory. ${ }^{24}$ Learning how to create agar plates through aseptic technique, learning how to hold the pipette, how to discard the tips, how to seal the tubes in one hand, use paraffin wax tape with the other, to hold an Eppendorf, operate the autoclave, and even the becoming-accustomed to gloves and all the practices of washing and segregating that are inherent to the organisation of the laboratory, all of these practices shape and train the body and the scientific thought process, alter time and space, all in order to control when and where bacteria can be safely exposed and interacted with. Such tacit knowledge ${ }^{25}$ developed through practice, is thus central to the engineer's understanding of bacteria.

\footnotetext{
${ }^{20}$ Polymerase chain reaction: a technique used to exponentially amplify the number of copies of a strand of DNA.

${ }^{21} \mathrm{Gel}$ electrophoresis is a technique used to separate out strands of DNA according to their length.

${ }^{22} \mathrm{~A}$ process of producing a purified sample of plasmid (circular) DNA strands.

${ }^{23}$ Antibiotics are used to isolate specific colonies of bacteria that carry antibiotic resistance genes so as to differentiate between those containing genes of interest on known plasmids and those not containing the genes of interest.

${ }^{24}$ Knorr-Cetina, Epistemic Cultures.

${ }^{25}$ Collins, Tacit and Explicit Knowledge.
} 
Indeed, the bacteria that our participants are most troubled by are not their genetically engineered, high-tech inventions but the everyday, robust and threatening bacteria that must be constantly expunged from the work of technical manipulation. The bacteria with which our SB colleagues deal with are, in important ways, sedate. They are less able to protect themselves, precisely because in many instances the genes that produce the molecules that enable them to survive in competition with other 'free' bacteria have been removed, so as to make them more pliable and more willing to undergo manipulation. So the work that goes into manipulating bacteria also makes them fragile. As they become more amenable to engineering processes, they also require ever greater care; the body becomes more skilled in engineering bacteria in as much as the bacteria become more at risk from the bodies that modify them:

I've been obsessively cleaning my hands whilst in the laboratory. I think some of the team think this is funny. Now that I've been trusted enough to actually contribute to the experiments in the lab it has suddenly dawned on me that I am actually pipetting living, genetically modified bacteria from tube-to-tube. These little beige blobs are the terrifying spectre that Frankennarratives promise will destroy me. So I am a little worried about getting them on me. And yet, they're the life-saving gloop that [synthetic biologist] thinks is going to lead us to a technobohemian utopia. They're also impossibly vital to the work of the team, and one little mistake in pipetting could ruin a lot of effort. All-in-all it has made me a little conflicted. Am I going to die here in the lab, or get super powers? Am I going to cure cholera or just screw everything up? I feel like I'm less of a risk now though. I did the transformation today without killing off the E. coli and it was good. ... Repetitively moving liquids around is getting easier, and I've stopped dropping everything. There's less spritzing now. Though the pipetting hasn't told me that much, we just saw the gel results and it looks like the experiment is working. Phew! (Author's ethnographic notes from experiments to create a cholera-sensing bacterium)

Through the technical process of bacterial manipulation engineers-cum-synthetic biologists, indeed, ethnographers as well, must learn the procedures of bacterial care and purification. But the process of bacterial manipulation is laborious and it is easy to make mistakes and to contaminate your culture. Moreover, everything is essentially invisible or indistinguishable until you get the results and by then it is often too late to do anything about your errors. So much in the laboratory thus seems delicate and prone to failure. The human body feels large and dangerous. One becomes aware of being coated with invisible molecules and must learn not to trust one's own eyes. Learning the physically dextrous skills of manipulation, from agar plating to pipetting, keeping the laboratory clean and making sure everything is labelled is all done to prevent contamination, not so much of the external environment, but of the tiny samples of bacteria into which goes so much effort, tacit knowledge and embodied skill.

\section{Sewage cultures: managing the body at risk}

Much like the laboratory, the sewage works is full of peculiar shapes, sounds and smells. But by contrast to our laboratory experiences of bacteria as manipulable and yet vulnerable, and of the body as a danger to the bacteria, when one approaches the waste water sewage facility it is the body that is at risk in this immediately daunting and threatening landscape. The most extraordinary difference about this space, in relation to the microbiological laboratories in which - as ethnographers - we were more at home, is the scale. Most of the site is open-air, organised around rectangular and circular pools full of water and rocks and sewage:

A process engineer points me towards a large circular wall, where a slim and rather precarious looking metal staircase leads up and over the top. Despite the wall's low height (it can't be 
much taller than the average male) there is the ominous sound of a waterfall, a powerful thrum of tons of water ceaselessly crashing from an intimidating height. I crawl, cautiously, up the metal staircase and am presented with a view out over a chasm, a vast, cavernous hole extending deep down into the ground. It is far deeper than I had expected and, I realise, I'm supposed to follow the metal bridge now in front of me that will take me out onto a small viewing platform hanging over the edge. I brave it, gripping the handrails and trying to preserve a modicum of dignity. I peer down into the gulf that roars with the sound of water hurtling from a circular pipe that must be at least as wide as I am tall. (Author's ethnographic notes from a waste water treatment facility)

Much like in the laboratory one immediately feels inept in this space. The human body, untrained in this geography is awkward; it feels clumsy. But one also feels fragile as one tries to manoeuvre along the various walkways and up and down stairs that link the arrangement of treatment pools and the impossibly large pipes that bring water in and out of the facility. The everyday becomes treacherous, so the floor, for example, is slippery from mud, sewage and water. The air is dense with a vapour that wets you like tropical air. Hoses are kept near to entrances to buildings for washing your boots as they are periodically caked, cleaned and caked again.

A new recruit to a water treatment facility, having worked there for only a few months, describes how strange he found it to start working in this space, and of the long process of learning to keep your body clean and safe. He muses on the fact that he never escapes showers: showers at home, showers at work; he points them out around the site. The process engineers on site also talk about 'double gloving' - wearing two pairs of gloves because they inevitably get wet and filthy and it is easier to keep a pair underneath dry and clean if you change the external pair more regularly. Hands, feet, faces, mouths and eyes all become vulnerable to exposure amidst all this grime. The wetness and sludge seem pervasive and one quickly realises quite how important water-proof clothes are, how significant a thick pair of socks can be. In short, the environment of the sewage facilities presses in on the body, coating it, infiltrating it, shaping it, demanding more and more of its management and monitoring.

In this space, one's body, surrounded at every turn by sewage and water, is constantly at risk. Indeed, the pools of water that contain bacteria used to treat sewage are deadly deep. They have oxygen bubbling from the bottom to aerate the water and thus keep the bacteria alive. This, the process engineers note - as we cross the pools - makes them even more lethal if you should fall in: 'You'd sink quicker than we could get to you'. Bacteria, then, are not the puny, vulnerable things in sewage treatment that they are in the lab. One does not learn a whole series of bodily processes designed to protect them from the natural world. The reverse is true. The bacteria are part of a context and system of transformation that is exceptionally dangerous for human bodies. So whilst one's body is similarly made skilful through routinised practices, it is for its own protection, not that of the bacteria.

There is another difference as regards the signification of risk in these contrasting spaces. The microbiological labs require plastic gloves and have important routines about hygiene and microbial control, but the risk is rarely visible on the white clothes or white gloves. Bacteria are effectively invisible in the lab and have to be made visible through an array of sophisticated and banal mechanisms, from the use of fluorescence microscopes to labelling freezer boxes. This invisibility of the danger both to the body and to the experimental assemblage has to be managed using a semiotic system that warns, organises and routinises movement and behaviour. In part, this system operates using signs on the walls (reminders to wash one's hands, put on a lab coat, etc.) but also on the basis of some of the equipment used (for example, the orange, wavering flame during aseptic plate spreading) and the generally 
pervasive presence of white. By contrast, the vastness of the sewage facility means there are important differences for the process engineers as regards the way in which bacteria are signified and experienced. The principle difference again having to do with scale: bacteria are unavoidably visible in the sewage facility because of the impossibly large numbers of them in the gigantic, gurgling pools of murky water.

As such, out here in the middle of the vast vats of sewage, the signs of bacteria and the experience of the body at risk are far more immediate and potent. Indeed, the body is the primary site of experience of bacteria in the waste water world as the microbiological is represented by signifiers of a much greater scale: the pouring of brown water from gigantic pipes; the sludge covering the ground; the ever-present smell. Thus dirt, sewage and mud are the objects through which the bacteria 'become visible', and visible as dangerous, in the waste water facility, which is a sign system far more immediate and tangible than is the sign system in the laboratory. It is one that draws on common Western notions of dirty and clean and the deeply established binary association of good/bad with white/black. ${ }^{26}$ It is clean that is signified in the near-omnipresent white of the laboratory but the reverse in the water treatment facility where everything is a murky brown that has to be scrubbed and blasted off the body and other surfaces. Whilst the academic synthetic biologist's engineering body is engaged in practices that often affirm an ontological association between bacteria and fragility, the body of the process engineer is inscribed by practices that affirm an association between bacteria and danger.

\section{Treatment cultures: immunological narrative and olfactory epistemology}

Indeed, not only are the bacteria persistent in their presence - in sewage contexts - on the surface of the body, as signified by mud and dirt, they also get inside the body, such that the body must adapt to their presence and co-habitation: 'When you first come to site you get ill being around this atmosphere. But your immune system takes to it after a bit. When I've been to other sites, I've gotten ill before, from stomach bugs' (Industrial water process engineer \#1). This small snippet is part of a more general story about being at work in water treatment facilities, having to do with the way in which one's body becomes adapted to the specific location in which one does one's work. As process engineer \#1 describes it, the human immune system 'takes to it' or as another process engineer (\#3) said, 'Once you've been ill, you build an immunity'. This idea of building immunity articulates a habituation to the danger of the bacteria such that they no longer cause symptoms of illness. One novice engineer on site described how he had been shocked by the presence of bacteria everywhere in the process, having expected chemicals and bleach he was confused to find himself getting sick from bacterial infection. As such, learning to be comfortable around the bacteria in the waste water treatment facility is, in part, a process of becoming used to the scale of the dangers and acclimatising to their hazardous characteristics. The body thus becomes understood through its local context as regards the bacterial community since, as process engineer \#1 described it above, 'When I've been to other sites, I've gotten ill before'. Indeed, a number of anecdotes were organised around the way in which novice engineers or visitors were ignorant of the potential to be infected by the bacteria. One such story, for example, concerned a group of electrical engineers who had been contracted to fix a problem with an aeration tank and who had all refused to wear masks over their mouths and then became ill, one-by-one, day-by-day until none of them were left to finish the job.

${ }^{26}$ Douglas, Purity and Danger; Mody, "Little Dirt Never Hurt." 
The purpose of these tales of illness and recovery, and in particular of the underlying notion that animates them, one of the body 'becoming accustomed' to its surroundings, is to induct the novice into the expert understanding of the body as adaptable. Significantly, the immunological construction does not match the classic military metaphor of the 'body at war' that persists in explanations of immunity, whereby the immune system defends the body against the dangerous outside. ${ }^{27}$ Whilst the process engineers are certainly aware of the dangerous quality of the bacteria, and are in the habit of managing the risk to their bodies through prevention (as regards their clothing, for instance) they nonetheless relate their immune system in more ecological terms, seeing their body as changing to fit the environment, and thus as 'flexible' but also resilient. They learn that their bodies somehow become 'at home' in these spaces, since it is other sites that pose the greatest risk of becoming sick, once one has, through habit, become acclimatised to the home treatment works.

This 'being in tune' with the environment was also present when the process engineers narrated another element of their local expertise. Since the bacteria are an important part of the process of water treatment, significant amounts of time and expense go into keeping them alive and capable of performing the aerobic processes required to degrade waste. The pools are so large that they need gigantic aeration devices to pump oxygen through the water to ensure the bacteria do not fall into anaerobic respiration. The experience of these sensitivities, for treatment process engineers, is partially mediated by technology, in that there are devices designed to measure the levels and automatically adjust the pools to maximise efficiency whilst minimising cost. However, there are certain measurements that the engineers lay claim to over and above the technical apparatus.

This has to do with the olfactory epistemology that the embodied engineer learns regarding the smell of the air in different locations within the sewage facility: the smell of the incoming water, of the bacterial pools, the smell of the post-treatment pipes and of the sludge and the mud. The engineers narrate their experience of different smells through a range of stories, describing different kinds of smells that help them determine whether the bacteria, in their words, are 'happy' or 'unhappy'. This often has to do with an anthropomorphic understanding of the bacteria as needing a particular diet of oxygen and waste water. If their diet is not right they smell different. One engineer, for instance, referred to the bad smell of bacteria that have too little oxygen as 'burger van smell'. Some on-site engineers claimed that the oxygen measuring apparatus could not always be trusted since it sometimes did not agree with the smell of the water. As such, the standards created in the software that monitors and changes the levels of oxygen is, for the process engineers, potentially suspect. They amend the values manually using their on-the-ground experience of the olfactory world of bacterial treatment. The process engineers thus relate a story of bacteria that are risky, that pose a threat to the body, but also understand their bodies as adapted to their environment and as sensitive to the bacteria to which they have adapted. Their understanding of bacteria is thus importantly understood in relation to the specific context in which their bodies and bacteria meet.

\section{Discussion: ontologies and 'barriers to innovation'}

As Sheppard et al. have pointed out, engineering practice often involves problem solving, with one important component of such work being collaboratively defining and understanding the problem. ${ }^{28}$ The problem of 'barriers to innovation' as defined by synthetic biologists

\footnotetext{
${ }^{27}$ Martin, Flexible Bodies.

${ }^{28}$ Sheppard et al., "What Is Engineering Practice?"
} 
(and engineers of other kinds), both nationally and in our local project, has much to do with ignorance, whether public or industrial. Such ignorance, they contest, hampers the translation of academic research into practical solutions in industrial contexts. It is no surprise that the focus of our academic engineering colleagues' dismay about barriers to SB in the water industry oriented around an anticipation of fear and ignorance of synthetic microorganisms.

In contrast, whilst still seeking to respond to the challenge of a barrier to innovation our sociological work sought to contribute to defining and understanding the problem in a different manner, so that ignorance was no longer the central concern. Instead, we replaced it with the meanings, or in our more technical terminology, with the ontologies of bacteria. Bringing work in STS and Engineering Studies into dialogue we framed our ethnographic work as being concerned with the ways ontological connections between bacteria, engineers and knowledge-making strategies were shaped through contextually bound practices. Two examples have proven instructive to our argument, namely those of the synthetic biologist in the laboratory and the process engineer in the water treatment facility.

Downey and Lucena suggest that professional engineering identities are likely as varied as are engineering contexts, and that, 'The analytical challenge in accounting for such diversity becomes showing how the epistemological values of engineering knowledge are linked to the wider social values of engineering work and the professional identities of engineers' ${ }^{29}$ Following a similar logic, we have argued that SB identities are intimately connected to the application of engineering in the context of biological manipulation, as are process engineers' identities to the management of bacteria in the water treatment facility. We quickly found that whilst in both environments the sights, sounds and smells were interesting and strange to us as ethnographers, there were some important differences and similarities that could be discerned. We drew one important distinction by showing how the body was instrumental to both the practices of lab engineers and process engineers but took on different meanings by virtue of its interaction with bacteria. We described how laboratory engineers seeking to manipulate bacteria have to train their bodies so that they can manipulate them successfully and so that their bodies are less of a risk to the survival of the bacterial culture. This meant that in their interaction with the rhetoric and logic of SB and through engagements with the human body bacteria were understood as controllable but also vulnerable, because, for instance, they lack certain genes that would otherwise help protect them against some of the forces in the laboratory. We argued that this continual practice of protecting the bacteria against the body, of cleaning the body, lab surfaces and equipment and so on, of sealing tubes, labelling, autoclaving, etc. helps routinise the ontological connection between the bacteria and fragility. In contrast, we observed how process engineers have to train their bodies so that they can safely move around the waste water treatment facility. They learn the practices that help keep them safe from falling into pools of sewage, from slipping on mud, etc. Moreover, the process engineers become skilled at managing their body, keeping it protected from the bacteria that surround it in the air, water and mud. We saw how this is necessary since the bacteria in the water treatment context appear as huge pools of sewage-digesting sludge, and are visibly ubiquitous in the local environment. The continual practice of protecting the body against the bacteria and the sign system of mud and dirt thus helps routinise the ontological connection between the bacteria and danger. As such, whilst both practices involved the body and bacteria, each routinised sequence of contextually specific action produced different ontological connections between them, shaping the meanings of both the bacteria and of the body.

${ }^{29}$ Downey and Lucena, "Knowledge and Professional Identity," 412. 
We also began to see how this skilling of the body with contextual practices is an important precursor to claiming expertise in working with bacteria in those contexts. So, without the tacit, embodied knowledge that the engineers in the laboratory must develop through practice, they would not be able to successfully manipulate bacteria and thus could not claim expertise in their genetics, processes and behaviours. Similarly, in the context of the waste water treatment facility the process engineers developed an immunological narrative of contextual adaptation that enables them to live 'at home' in the facility and to be healthy in that specific context. Moreover, they use this relation to establish a local expertise of olfactory epistemology, developing practices for understanding and managing the bacterial metabolic processes that are unavailable to unskilled, 'foreign' bodies. In each of these contexts, then, the practices that relate bacteria to the body form an important foundation for claims of expertise as professional, competent engineers.

Thus, the meanings of 'engineer' of 'the body' and of 'bacteria' are all interrelated in specific contexts, such that none of these terms has a sensible meaning outside of these immediate relations. Their meanings cannot be carried across other contexts without losing the specificity of their definition within particular practices of routinised, embodied, engineering work with bacteria. Demonstrating the embodying of these ontological connections through practice has been the principle contribution of this paper to the study of $\mathrm{SB}$, of engineering and engineering identities.

But, returning to the challenge set by the project and by our engineering colleagues, our work also promises some significance to the study of 'barriers to innovation'. In the process of problematising the uptake of SB, our engineering colleagues both local and national adopted ignorance as the central concern. They emphasised how public actors over-estimate the risk posed by bacteria, and bemoaned their lack of understanding how controlled and contained bacteria are. The response to such a problematisation is, for synthetic biologists, to educate through engagement and to appeal to regulators for understanding. We began from a similar starting point: a concern with how SB might be understood in other contexts. However, our problematisation took meanings of bacteria as its central concern and thus charted a different description of the problem, and thus - we believe - entails different responses. If the 'barriers' are not simply ignorance of the truth but rather differences in practice-based ontological relations, then the solution cannot be education. Instead, academic actors might be more usefully sensitised to their own contextually bound understandings of the objects with which they work. Synthetic biologists and academic engineers of other sorts might be more able to discuss their work, their innovations and aspirations if they are better able to ground it in their lived, embodied experience of laboratory practices. They might also come to see the ways in which other views are similarly formed through contextually bound practices.

Identifying a perhaps inadvertent adoption by STS scholars of the 'downstream' notion of engineering, Downey and colleagues have emphasised the need to increase the visibility of engineers as actors subject to critical scrutiny, and to study engineering cultures and identities as 'upstream' activities rather than merely at the 'applications' end of scientific practices. ${ }^{30}$ Our work has addressed some of this challenge in the context of SB by showing how engineering expertise is firmly rooted in embodied, upstream practices as well as downstream applications. Acknowledging the bounded nature of these ontologies of the body, bacteria and engineering has at least one important policy implication. Such embodied expertise of researchers working with bacteria in laboratories is not necessarily

${ }^{30}$ Downey, "What Is Engineering Studies for?"; Downey and Lucena, "Knowledge and Professional Identity." 
the most appropriate for appraising the potential risks associated with the deliberate release of genetically engineered bacteria into the environment. Expertise in the laboratory is not necessarily expertise in 'the field' of application. In this regard, different ontologies of bacteria might be taken into account when constituting engineering solutions such as those developed by synthetic biologists. In this manner, actors from publics of other sorts might be able to ask questions of engineers, make objections to assumptions, critically evaluate aspirations and innovations, and - perhaps more importantly - contribute to the process of innovation. For example, the local expertise developed by process engineers as regards the management of bacteria in relation to their bodies would make a valuable contribution to discussions of how to design bacteria for use in those locations and would be invaluable to understanding the ways in which such bacteria are likely to be engaged with. Locating expertise in practices by relation to ontologies could open-up discussion of SB in ways that are closed by problematising innovation barriers using tropes of 'ignorance'.

Finally, perhaps we sociologically minded guests of the laboratory have ourselves failed to keep this in mind when bemoaning the rather common perspective held by those in SB as regards the management of ethics, risk and safety. We might too easily overlook that it is not only a discursive production of expertise, a rhetoric of governance and a vestige of Enlightenment ideology, but also a relation to, and an understanding of, the meaningfulness of bacteria that is inscribed through practice into the performance of the engineering body. Sociological ethnographies in the context of engineering projects such as those currently constituting the work of SB might instructively contribute to the process of innovation by helping engineers understand alternative accounts of their work and to understand how their own expertise is shaped.

\section{References}

Bhattachary, Darren, Juliet P. Calitz, and Andrew Hunter. Synthetic Biology Dialogue. London, UK: TNS-BMRB and the Biotechnology and Biological Sciences Research Council and Engineering and Physical Sciences Research Council, 2010. http://www.bbsrc.ac.uk/web/FILES/Reviews/ 1006-synthetic-biology-dialogue.pdf.

Bovy, Michel, and Dominique Vinck. "Social Complexity and the Role of the Object: Installing Household Waste Containers." In Everyday Engineering: An Ethnography of Design and Innovation, ed. Dominique Vinck, 53-75. Cambridge, MA: MIT Press.

Bucciarelli, Louis L. "An Ethnographic Perspective on Engineering Design.” Design Studies 9, no. 3 (1988): 159-68.

Calvert, Jane. "Synthetic Biology: Constructing Nature?" Sociological Review 58, no. s1 (2010): 95-112.

Collins, Harry. Tacit and Explicit Knowledge. Chicago: University of Chicago Press, 2010.

Douglas, Mary. Purity and Danger: An Analysis of the Concepts of Pollution and Taboo. London: Routledge, 1966.

Downey, Gary Lee. "What Is Engineering Studies For? Dominant Practices and Scalable Scholarship." Engineering Studies 1, no. 1 (2009): 55-76.

Downey, Gary Lee, and Juan C. Lucena. "Knowledge and Professional Identity in Engineering." History and Technology 20, no. 4 (2004): 393-420.

Knorr-Cetina, Karin. Epistemic Cultures: How the Sciences Make Knowledge. Cambridge MA: Harvard University Press, 1999.

Latour, Bruno. Reassembling the Social: An Introduction to Actor-Network Theory. Oxford: Oxford University Press, 2005.

Law, John, and Annemarie Mol. "Situating Technoscience: An Inquiry into Spatialities." Environment and Planning D: Society and Space 19, no. 5 (2001): 609-21.

Marcus, George E. "Ethnography in/of the World System: The Emergence of Multi-Sited Ethnography." Annual Review of Anthropology 24 (1995): 95-117. 
Marris, Claire. "The Elephant in the Room." Paper presented at the European association for the Study of Science and Technology/Meeting of the Society for Social Studies of Science (EASST/4S) Conference, Copenhagen, October 20, 2012.

Martin, Emily. Flexible Bodies: Tracking Immunity in American Culture: From the Days of Polio to the Age of AIDS. Boston, MA: Beacon Press, 1994.

Mody, Cyrus C.M. "A Little Dirt Never Hurt Anyone: Knowledge-Making and Contamination in Materials Science." Social Studies of Science 31, no. 1 (2001): 7-36.

Mol, Annemarie. The Body Multiple: Ontology in Medical Practice. Durham: Duke University Press, 2002.

O'Malley, Maureen, Alexander Powell, Jonathan Davies, and Jane Calvert. "Knowledge-Making Distinctions in Synthetic Biology." BioEssays 30, no. 1 (2008): 57-65.

Paretti Marie C., and Lisa D. McNair. "Analyzing the Intersections of Institutional and Discourse Identities in Engineering Work at the Local Level." Engineering Studies 4, no. 1 (2012): 55-78.

Sheppard, Sherri, Anne Colby, Kelly Macatangay, and William Sullivan. "What Is Engineering Practice?" International Journal of Engineering Education 22, no. 3 (2006): 429-38.

Vinck, Dominique. Everyday Engineering: An Ethnography of Design and Innovation. Cambridge, MA: MIT Press, 2003.

Vinck, Dominique, and Nathalie Ravaille. "Contrasting Design Cultures: Designing Dies for Drawing Aluminum." In Everyday Engineering: An Ethnography of Design and Innovation, ed. Dominique Vinck, 93-117. Cambridge, MA: MIT Press. 